13,12

\title{
Характеризация тонких углеродных пленок на поверхности железа, сформированных магнетронным напылением с ионно-лучевым перемешиванием
}

\author{
(C) Т.С. Картапова ${ }^{1}$, О.Р. Бакиева ${ }^{1}$, В.Л. Воробьев ${ }^{1}$, А.А. Колотов ${ }^{1}$, О.М. Немцова ${ }^{1}$, \\ Д.В. Сурнин ${ }^{1}$, Г.М. Михеев ${ }^{2}$, Ф.З. Гильмутдинов ${ }^{1, \uparrow, ~ В . Я . ~ Б а я н к и н ~}{ }^{1}$ \\ ${ }^{1}$ Физико-технический институт УрО РАН, \\ Ижевск, Россия \\ ${ }^{2}$ Институт механики УрО РАН, \\ Ижевск, Россия \\ ฯ E-mail: ftiran@mail.ru
}

(Поступила в Редакцию 2 августа 2016 г.)

\begin{abstract}
Методами рентгеновской фотоэлектронной спектроскопии, рентгеноструктурного анализа, спектроскопии протяженных тонких структур энергетических потерь электронов и спектроскопии комбинационного рассеяния света изучены химический состав, межатомная химическая связь и особенности атомной структуры наноразмерных углеродных пленок на поверхности железа, полученных магнетронным напылением, до и после ионно-лучевого перемешивания. В зоне ионно-лучевого перемешивания обнаружены структурные неоднородности и нестехиометрические карбиды железа. Определены параметры локальной атомной структуры сверхтонкого поверхностного слоя и переходной области „углеродная пленка-металл“.
\end{abstract}

Работа выполнена при финансовой поддержке РФФИ (проект № 16-43-180765) и проекта УМНИК, дог. № 9302 ГУ2015.

DOI: 10.21883/FTT.2017.03.44176.315

\section{1. Введение}

Углеродные пленки, в том числе пленки аморфного, наноструктурированного и алмазоподобного углерода, находят широкое применение в качестве износостойких покрытий для жестких дисков, оптических устройств, а также в полупроводниковых технологиях и электрохимических приложениях [1-2]. Универсальность углеродных материалов определяется их структурой и характером межатомных связей, в частности зависимостью их физических свойств от соотношения $s p^{2}-$ и $s p^{3}$-гибридизованного углерода [3]. Среди практических приложений представляют интерес тонкие углеродные пленки на металлических поверхностях, которые могут обладать рядом полезных функциональных свойств в сочетании с высокими механическими характеристиками [4-8]. В частности, прогнозируется их высокая коррозионная стойкость [9]. Среди множества методов формирования покрытий и пленок с заданными свойствами перспективными являются методы ионнолучевой обработки [10], в частности воздействие потоком высокоэнергетичных ионов на предварительно нанесенные магнетронным способом на поверхность мишени нанослои легирующего вещества, что позволяет формировать наноразмерные покрытия с высокой адгезией к подложке. При этом ионная бомбардировка существенно влияет на структуру углеродных пленок и характер межатомного взаимодействия, что, в свою очередь, определяет их свойства. Ранее в [11] нами было показано, что бомбардировка ионами $\mathrm{Ar}^{+}$тон- ких углеродных пленок на поверхности армко-железа приводит к улучшению механических и коррозионных свойств. Несмотря на многочисленные исследования в этой области, процессы формирования наноразмерных углеродных и смешанных углеродно-карбидных покрытий на металлических поверхностях при ионно-лучевом перемешивании компонентов поверхностного слоя изучены недостаточно. В связи с этим целью данной работы явилось комплексное исследование поверхностночувствительными методами химического состава, межатомных химических связей, атомной и локальной атомной структуры тонких углеродных пленок, сформированных на поверхности железа методом магнетронного напыления с последующей ионно-лучевой обработкой потоком высокоэнергетичных ионов $\mathrm{Ar}^{+}$.

\section{2. Техника эксперимента}

Образцы армко-железа представляли собой пластины с размерами $9 \times 9 \times 2 \mathrm{~mm}$, поверхность которых подвергали механической шлифовке, полировке с использованием полирующих паст и последующей очистке промывкой в органических растворителях в ультразвуковой ванне. Образцы были подвергнуты термообработке при температуре $923 \mathrm{~K}$ в течение $0.5 \mathrm{~h}$ в вакууме $\sim 10^{-4} \mathrm{~Pa}$.

Пленки углерода на поверхности армко-железа были осаждены методом магнетронного напыления на постоянном токе с использованием графитовых мишеней в установке „Катод-1М““ при температуре подложки 473 K. 
Остаточное давление в камере напыления составляло $10^{-4} \mathrm{~Pa}$. Напуск аргона производился до рабочего давления $2 \cdot 10^{-1} \mathrm{~Pa}$. Толщина пленок была измерена на микроинтерферометре МИИ-4, а также методом АСМ на контрольных образцах, и составила в среднем 30-35 nm. Полученные пленки визуально имели темно-серый блестящий цвет и обладали стойкостью к истиранию.

Ионно-лучевое перемешивание пленок углерода проводили бомбардировкой ионами $\mathrm{Ar}^{+}$с энергией $30 \mathrm{keV}$ с дозами $D=5 \cdot 10^{16}$ и $10^{17} \mathrm{ion} / \mathrm{cm}^{2}$ вертикально к поверхности мишени в установке на базе сверхвысоковакуумного поста УСУ-4 с плазменным источником ионов с ненакаливаемым катодом импульсно-периодического действия „Пион-1M“ с длительностью импульса $1 \mathrm{~ms}$, частотой следования импульсов $100 \mathrm{~Hz}$ и плотностью тока в импульсе $100 \mathrm{~A} / \mathrm{cm}^{2}$. Параметры облучения выбраны с тем условием, чтобы глубина ионного распыления не превысила толщину углеродной пленки, при этом проективный пробег достигал или превышал границу раздела пленка/подложка. Проективный пробег ионов $\mathrm{Ar}^{+}$в графите при кинетической энергии ионов $30 \mathrm{keV}$ составляет $\sim 25 \mathrm{~nm}[12]$ и, таким образом, соизмерим с исходной толщиной напыленных пленок.

В процессе облучения с помощью термопары контролировалась температура образцов, до которой происходил их разогрев под действием ионного пучка. Температура образцов в конце облучения с выбранными дозами не превышала $80^{\circ} \mathrm{C}$ и $140^{\circ} \mathrm{C}$ соответственно. Остаточное давление в камере облучения составляло $10^{-4} \mathrm{~Pa}$, давление аргона высокой чистоты при имплантации достигало $10^{-1} \mathrm{~Pa}$. После облучения изначально темно-серая поверхность покрытий приобретала светло-бежевый оттенок, блеск и прозрачность.

Химический состав углеродных пленок исследован методом рентгеновской фотоэлектронной спектроскопии (РФЭС) на спектрометре SPECS с использованием $\mathrm{A} 1 K_{\alpha}$-излучения $(1486.6 \mathrm{eV})$ в сочетании с послойным травлением поверхности ионами аргона с энергией $4 \mathrm{keV}$ и плотностью тока $30 \mathrm{~A} / \mathrm{cm}^{2}$ (скорость травления $\sim 1 \mathrm{~nm} / \mathrm{min}$ ). Экспериментальные данные обработаны с помощью пакета программ CasaXPS. Относительная погрешность определения концентрации элементов составляла $\pm 3 \%$ от измеряемой величины.

Исследования локальной атомной структуры сверхтонкого поверхностного слоя и переходного слоя „пленка/подложка“ проведены методом анализа протяженных тонких структур энергетических потерь электронов (EELFS - Extended Energy Loss Fine Structure) [13-15]. Данный метод, так же как и XAFS ( $X$-ray Absorption Fine Structure) исследования, позволяет определять параметры локального атомного окружения. Однако, в отличие от XAFS, использование возбуждения внутреннего уровня атома электронным ударом позволяет варьировать глубину анализа, изменяя энергию возбуждения, а также определять параметры локального окружения относительно атома легкого элемента. Протяженные тонкие структуры спектров энергетических потерь электронов за $\mathrm{M}_{2,3}$ краем возбуждения железа и $\mathrm{K}$ краем возбуждения углерода были получены в геометрии обратного рассеяния вторичных электронов от поверхности образца, в интегральном режиме (режим ВВМ - Beam Brightness Modulation) на Оже-микрозонде JAMP-10S (JEOL). Анализ EELFS спектров железа и углерода проводился с использованием методики [14,15].

Спектры комбинационного рассеяния света пленок снимались с помощью спектрометра HORIBA Jobyn Yvon HR800 с использованием гелий-неонового лазера $\left(\lambda_{\mathrm{ex}}=632.8 \mathrm{~nm}\right)$ и объектива со 100-кратным увеличением $(100 \mathrm{X})$. Диаметр лазерного пучка $-5 \mu \mathrm{m}$, время экспозиции - $5 \mathrm{~s}$.

\section{3. Результаты экспериментов и их обсуждение}

На рис. 1 приведены концентрационные профили распределения элементов в приповерхностных слоях образцов армко-железа с нанесенной пленкой углерода и после ее облучения ионами аргона. В результате облучения происходит „размытие“ исходных профилей элементов и формирование переходного слоя протяженностью не менее $20 \mathrm{~nm}$ с взаимным проникновением атомов углерода в подложку и атомов железа в пленку, а также смещение границы раздела „пленка/подложка“ к поверхности. Смещение границы раздела к поверхности обусловлено частичным распылением слоя углерода ионной бомбардировкой.

Ранее в [11] нами было показано, что наилучшие результаты коррозионно-электрохимического поведения армко-железа с углеродным покрытием в нейтральных и кислых средах показывают образцы, облученные ионами $\mathrm{Ar}^{+}$с энергией $30 \mathrm{keV}$ и дозой $10^{17} \mathrm{ion} / \mathrm{cm}^{2}$. Поэтому в данной работе проведены подробные исследования углеродных пленок, модифицированных именно при этих параметрах.

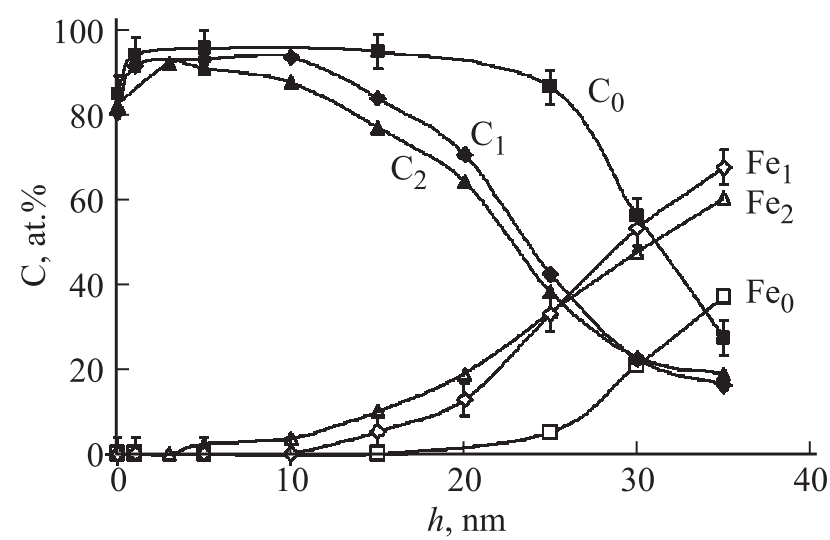

Рис. 1. Распределение элементов в поверхностных слоях армко-железа с поверхностной пленкой углерода в исходном состоянии (0) и после облучения ионами $\mathrm{Ar}^{+}$с энергией $30 \mathrm{keV}, D=5 \cdot 10^{16}(1), 10^{17} \mathrm{ion} / \mathrm{cm}^{2}(2)$. 

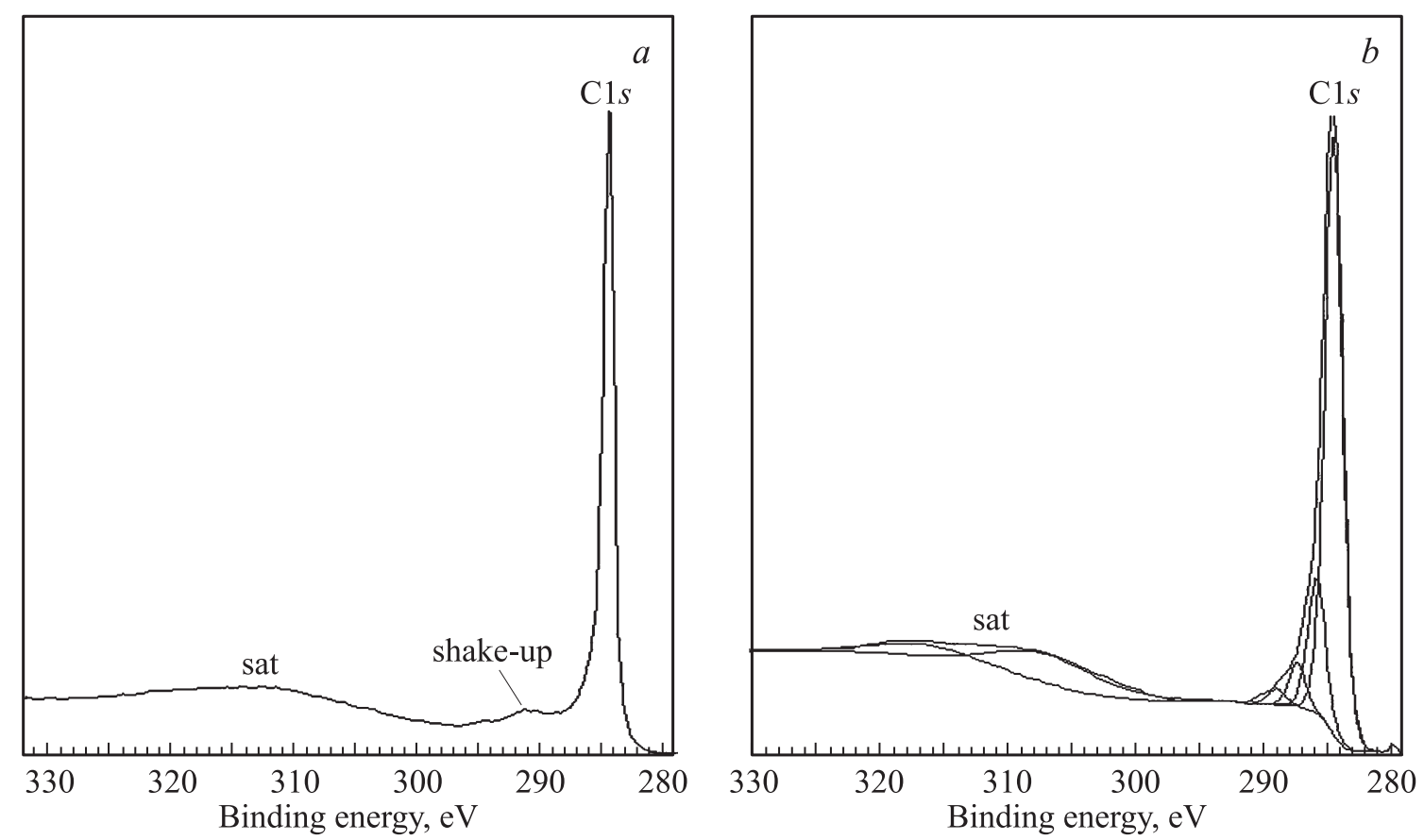

Рис. 2. $\mathrm{C} 1 s$-спектр высокоориентированного пиролитического графита $(a)$ и углеродного покрытия на железе после ионного облучения $(b)$ с сателлитной структурой.

$\mathrm{C} 1 s$-спектр поверхности ионно-модифицированной углеродной пленки с областью плазмонных потерь отличается от спектра эталонного высокоориентированного графита уширением основного пика с асимметрией в сторону более высоких значений энергий связи и изменением структуры сателлита плазмонных потерь (рис. 2). Полная ширина на половине высоты (ПШПВ) основного пика возрастает от значения $1.05 \mathrm{eV}$ для графита до $1.59 \mathrm{eV}$ для углеродной пленки до облучения и до $1.86 \mathrm{eV}$ для углеродной пленки после ионной бомбардировки. Появляется плазмонный пик в области энергий связи $318-320 \mathrm{eV}$, который может быть связан с наличием $s p^{3}$-гибридизованного углерода и с разупорядоченностью структуры пленки. Данный пик потерь наиболее выражен для ионно-облученных пленок.

Подробный послойный анализ рентгеновских фотоэлектронных $\mathrm{C} 1 s$-спектров углеродных пленок с использованием данных эталонных образцов и справочных данных $[16,3]$ показал, что углерод в пленке и на границе раздела „пленка/подложка“ находится в нескольких химически неэквивалентных состояниях (рис. 3). Пик с $E_{b}=284.6 \mathrm{eV}$ соответствует углероду в связи $\mathrm{C}-\mathrm{C}\left(s p^{2}\right.$-гибридизация) и характерен для графита и графитоподобных структур. Пик с $E_{b}=286 \mathrm{eV}$ может быть отнесен к углероду в химической связи, характерной для структуры алмаза ( $s p^{3}$-гибридизация) или разупорядоченного углерода [3]. Уширение спектров $\mathrm{C} 1 s$ углеродных пленок на железе, по сравнению с пиролитическим графитом, связано главным образом с появлением и ростом именно этого пика. Одновременно в спектре сателлита плазмонных потерь наблюдается компонента на $E_{b}=318-320 \mathrm{eV}$. Вблизи границы раздела „C/Fе“ ее относительная интенсивность максимальна. Слабоинтенсивные пики спектра $\mathrm{C} 1 s$ в области 287-289 eV - фотоэмиссия от атомов углерода, взаимодействующих с кислородом. Пик с $E_{b}=283.5 \mathrm{eV}$ относится к углероду в химической связи с железом $\mathrm{C}-\mathrm{Fe}$. Химическое взаимодействие углерода с железом c образованием $\mathrm{C}-\mathrm{Fe}$ связей наблюдается на границе „пленка/подложка“ еще до ионно-лучевой обработки. В результате ионного облучения доля углерода в связи $\mathrm{C}-\mathrm{Fe}$ существенно возрастает, а вблизи границы раздела „пленка/подложка“ становится преобладающей. Это позволяет предположить, что в результате ионной бомбардировки в зоне перемешивания могут возникать карбиды железа, а учитывая, что химический состав анализированного слоя в целом неоднороден и материал подвергался ионной бомбардировке, следует ожидать возникновения соответствующих структурных неоднородностей переменного состава. В целом из анализа $\mathrm{C} 1 s$ спектров и их сателлитов следует вывод о разупорядоченности структуры углеродных пленок и наличия в них $s p^{3}$-гибридизованного углерода до $18-20 \%$ от общего количества.

Рентгеноструктурные исследования образцов в геометрии скользящего пучка $\left(\alpha=0.1^{\circ}\right)$ с расчетной глубиной анализа $50-70 \mathrm{~nm}$, захватывающей углеродную пленку и прилегающую область материала подложки, показали, что после облучения ионами $\mathrm{Ar}^{+}$рефлексы структуры $\alpha-\mathrm{Fe}$ сдвигаются в сторону меньших углов с размытием их левых „крыльев“ в эту же область 

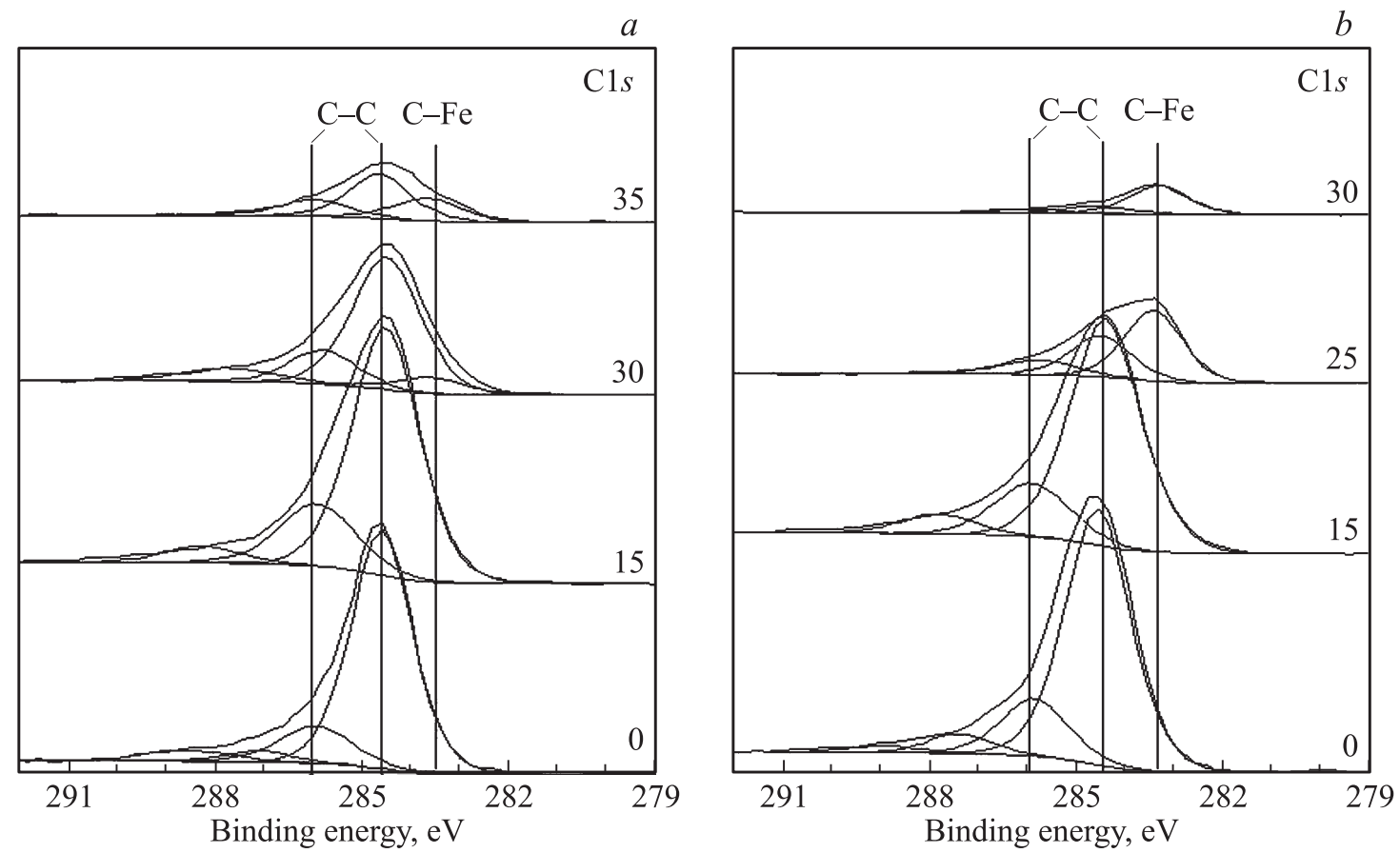

Рис. 3. Рентгеноэлектронные спектры $\mathrm{C} 1 s$ углеродной пленки на армко-железе до $(a)$ и после облучения $(b)$ ионами аргона $\left(E_{i}=30 \mathrm{keV}, D=10^{17} \mathrm{ion} / \mathrm{cm}^{2}\right)$. Цифры справа - глубина от поверхности $(\mathrm{nm})$.

(рис. 4). Это может быть связано с увеличением параметра решетки $\alpha-\mathrm{Fe}$ в результате внедрения углерода в материал подложки, а также с возникновением структурных неоднородностей в зоне ионно-лучевого перемешивания. Важно отметить, что признаков упо-

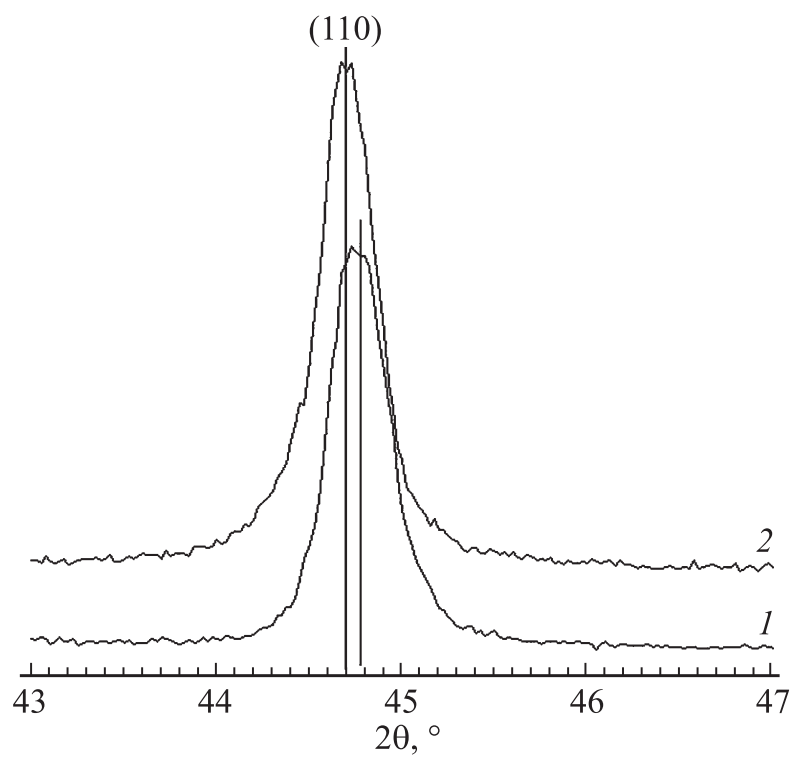

Pис. 4. Участок дифрактограммы поверхностных слоев армкожелеза с пленкой углерода до (1) и после (2) ионного облучения $\left(E_{i}=30 \mathrm{keV}, D=10^{17} \mathrm{ion} / \mathrm{cm}^{2}\right)$. Съемка в геометрии скользящего пучка (фиксированный угол между первичным пучком и поверхностью образца $\alpha=0.1^{\circ}$, глубина анализа $50-70 \mathrm{~nm})$. рядоченной структуры графита на дифрактограммах исследованных образцов не выявлено. Таким образом, данные РСА согласуются с выводами результатов РФЭС о разупорядоченности углеродных пленок, возникновении неоднородностей структуры на границе раздела „пленка/подложка“ и возможном образовании карбидов железа переменного состава.

При этом остается открытым вопрос о локальной атомной структуре сверхтонкого поверхностного слоя (до $3 \mathrm{~nm}$ ), состоящего, по данным РФЭС, преимущественно из углерода (рис. 1), и структуре переходного слоя.

Исследования локальной атомной структуры поверхности углеродной пленки до и после ионно-лучевого облучения ионами $\mathrm{Ar}^{+}$проведены методом EELFS спектроскопии. Получены EELFS спектры за К краем возбуждения углерода при энергии падающего электронного пучка $1700 \mathrm{eV}$, что соответствует глубине анализа не более $5 \mathrm{~nm}$. В результате анализа К-EELFS спектров углерода определены параметры локального атомного окружения относительно атома углерода в пределах первой координационной сферы (табл. 1). Полученные результаты показывают, что после ионной бомбардировки межатомное расстояние углерод-углерод увеличивается до $1.5 \AA$. Эта величина не характерна для структуры графита и может быть связана с тем, что в поверхностном слое, подвергнутом ионной бомбардировке, углерод находится в разупорядоченном состоянии. При этом до ионного облучения межатомное расстояние $\mathrm{C}-\mathrm{C}$ в первой координационной сфере соответствовало значению для графита. 
Локальная атомная структура переходного слоя „пленка/подложка“ исследована после удаления внешнего углеродного слоя до глубины $35 \mathrm{~nm}$ травлением ионами аргона с энергией $4 \mathrm{keV}$ с плотностью тока $30 \mu \mathrm{A} / \mathrm{cm}^{2}$ при угле падения $45^{\circ}$ к поверхности. C учетом проективного пробега и угла падения ионов расчетная средняя глубина внедрения ионов аргона в мишень составляет $\sim 2.3 \mathrm{~nm}$ от поверхности. Параметры воздействия при ионном травлении существенно „мягче“ соответствующих параметров, используемых при ионнолучевом перемешивании (энергия ионов в 8 раз меньше, а плотность ионного тока в 3.3 раза меньше). Поэтому данные условия травления не оказывают заметного влияния на результат ионно-лучевого перемешивания углеродной пленки и железа при бомбардировке аргоном с энергией $30 \mathrm{keV}$ вертикально к поверхности мишени.

M2,3-EELFS спектры железа были получены при энергии падающих электронов $1100 \mathrm{eV}$ и $2300 \mathrm{eV}$, что обеспечило глубину анализируемого слоя поверхности образцов около $3 \mathrm{~nm}$ и $10 \mathrm{~nm}$ соответственно. Анализ полученных спектров позволил определить межатомные расстояния и параметры их дисперсии для пар атомов железо-углерод (табл. 2). Показано, что с увеличением

Таблица 1. Параметры локальной атомной структуры (межатомное расстояние $R_{\mathrm{C}-\mathrm{C}}$ и параметры среднеквадратичного отклонения атомов $1 / 3\left\langle\Delta R^{2}\right\rangle$ ) сверхтонких поверхностных слоев исследуемых объектов

\begin{tabular}{c|l|l|c}
\hline \multicolumn{1}{c|}{ Образец } & \multicolumn{1}{|c|}{ Вид данных } & $R, \AA$ & $1 / 3\left\langle\Delta R^{2}\right\rangle, \AA^{2}$ \\
\hline \multirow{2}{*}{ Эталон $\mathrm{Fe}_{3} \mathrm{C}$} & $\begin{array}{l}\text { Экспериментальные } \\
\text { данные }\end{array}$ & 3.1 & 0.003 \\
\cline { 2 - 4 } & $\begin{array}{l}\text { Кристаллографические } \\
\text { данные (цементит) }\end{array}$ & 3.1224 & 0.00295 \\
\hline $\begin{array}{l}\text { Пленка C/Fe } \\
\text { до ионного } \\
\text { облучения }\end{array}$ & $\begin{array}{l}\text { Экспериментальные } \\
\text { данные }\end{array}$ & 1.4 & 0.003 \\
\cline { 2 - 4 } & $\begin{array}{l}\text { Кристаллографические } \\
\text { данные (графит) }\end{array}$ & 1.418 & 0.0026 \\
\hline $\begin{array}{l}\text { Пленка C/Fe } \\
\text { после ионного } \\
\text { облучения }\end{array}$ & $\begin{array}{l}\text { Экспериментальные } \\
\text { данные }\end{array}$ & 1.5 & 0.003 \\
\hline
\end{tabular}

Таблица 2. Параметры локальной атомной структуры (межатомное расстояние $R_{\mathrm{Fe}-\mathrm{C}}$ и параметры среднеквадратичного отклонения атомов $\left.1 / 3\left\langle\Delta R^{2}\right\rangle\right)$ переходного слоя пленка/подложка

\begin{tabular}{c|c|c}
\hline $\begin{array}{c}\text { Глубина } \\
\text { анализа, } \mathrm{nm}\end{array}$ & $R_{\mathrm{Fe}-\mathrm{C}}, \AA$ & $1 / 2\left\langle\Delta R^{2}\right\rangle, \AA^{2}$ \\
\hline 3 & 1.9 & 0.06 \\
10 & 2.2 & 0.08
\end{tabular}

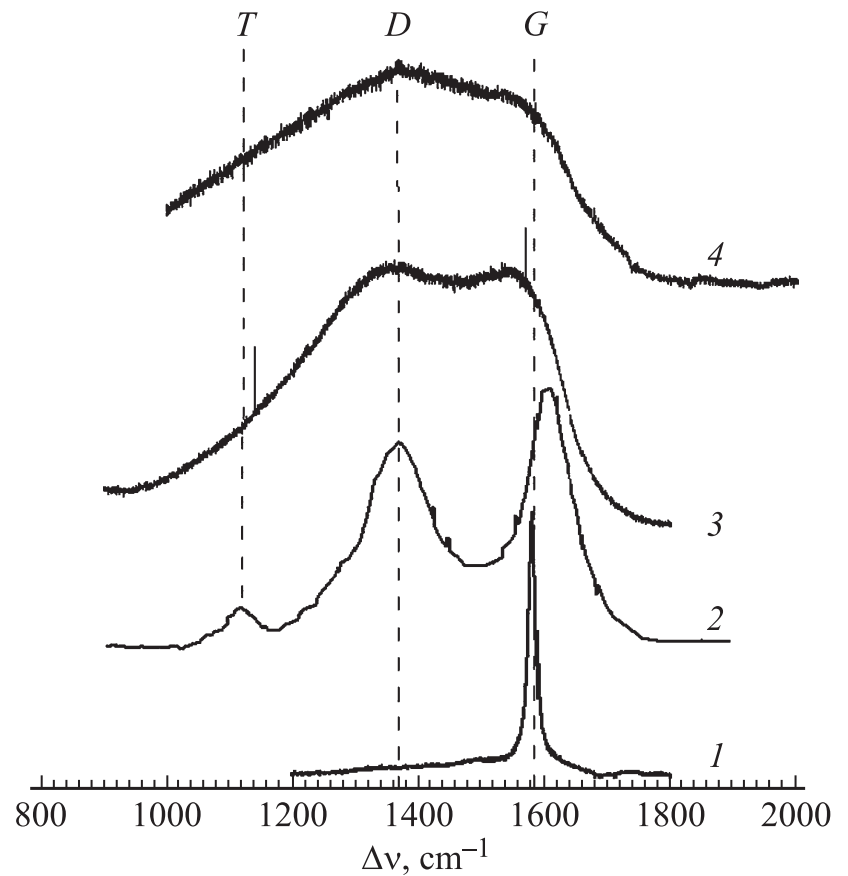

Рис. 5. Спектры комбинационного рассеяния света высокоориентированного графита $(1)$, разупорядоченного графита (угольный электрод) (2), магнетронной пленки углерода на железе (3) и пленки, дополнительно облученной аргоном $E_{i}=30 \mathrm{keV}, D=10^{17} \mathrm{ion} / \mathrm{cm}^{2}(4)$.

глубины анализа возрастает межатомное расстояние для пары атомов железо-углерод, что может свидетельствовать об уменьшении содержания углерода по глубине переходного слоя. Кроме того, данные значения отличаются от межатомных расстояний для стехиометрических соединений железа с углеродом: например, для $\mathrm{Fe}_{3} \mathrm{C}$ межатомное расстояние $\mathrm{Fe}-\mathrm{C}$ составляет $2.0 \AA$. Поэтому полученные результаты позволяют предположить, что на границе раздела пленка/подложка после ионно-лучевого перемешивания углерод и железо образуют нестехиометрические соединения переменного состава. Полученные результаты позволяют также предполагать о сильно разупорядоченной структуре анализируемого слоя с отсутствием дальнего порядка, что проявляется в наличии только пика первой координационной сферы на парной корреляционной функции $\mathrm{Fe}-\mathrm{C}$.

Для получения более полной картины о нанесенных на поверхность железа углеродных пленках представляет интерес исследование их спектров комбинационного рассеяния света (КРС). На рис. 5 представлены спектры комбинационного рассеяния света углеродных пленок до и после облучения ионами аргона в сравнении со спектрами высокоориентированного пиролитического графита и мелкодисперсного угольного электрода. КРС-спектр (1) эталонного высокоориентированного графита, снятый с графеновой плоскости, верхний тонкий слой с которого был предварительно 
удален скотчем, полностью соответствует аналогичным КРС-спектрам, опубликованным в литературе, и состоит из единственного узкого пика $G\left(1582 \mathrm{~cm}^{-1}\right)[1,2]$. На спектре (2) разупорядоченного графита, вырезанного из угольного электрода высокой чистоты, состоящего из множества микрочастиц, присутствуют две широкие интенсивные полосы $G\left(1600 \mathrm{~cm}^{-1}\right)$ и $D\left(1375 \mathrm{~cm}^{-1}\right)$, которые обусловлены C-С связями и $s p^{2}$-гибридизацией валентных электронов. Согласно [1] положение $G$ пика зависит от структуры материала и возрастает при переходе от структуры графита к нанокристаллическому состоянию. Наличие $D$-полосы соответствует разопорядоченному углероду. Ее происхождение связывают с нарушением правил отбора за счет конечных размеров кристаллитов, разупорядоченности и разного рода дефектов. Чем выше отношение интенсивностей $D / G$ и ширина полос, тем выше степень разупорядочения. На этом же спектре выделяется полоса в области $1120 \mathrm{~cm}^{-1}$, которая по литературным данным может быть отнесена к $T$-полосе. Полоса $T$ в литературе объясняется неоднозначно: деформацией графеновых плоскостей, аморфным состоянием, наличием $s p^{3}$-гибридизованного углерода и др. В целом спектр (2) аналогичен спектру сажи (аморфный углерод), приведенному в [17].

КРС-спектр (3) углеродной пленки, полученной магнетронным напылением, представлен двумя сильно размытыми полосами $D$ и $G$ с соотношением интенсивностей $D / G \sim 1$. Кроме того, спектр размыт влево от $D$-полосы в область низких частотных сдвигов. Малый „провал“ между двумя полосами может быть связан с наличием в этой области $\left(\sim 1480 \mathrm{~cm}^{-1}\right)$ еще одной полосы, относящейся к разупорядоченному $s p^{3}$-гибридизованному углероду. Следует отметить, что аналогичный спектр такой же пленки, нанесенной на ситалловую пластину (когда нет железа и углерода, связанного с ним), представлен более разрешенными пиками $D$ и $G$. Поэтому есть основание полагать, что слабый провал между этими пиками на спектре углеродной пленки на железной подложке частично связан с формированием полосы от структур $\mathrm{C}-\mathrm{Fe}$. Таким образом, согласно данным спектров КРС, пленка углерода, напыленная магнетронным методом, является пленкой, состоящей из разупорядоченного, преимущественно $s p^{2}$-гибридизованного углерода, с незначительной долей $s p^{3}$-углерода. При этом сильное размытие спектра в целом естественно связать с высокой структурной неоднородностью пленки по глубине анализируемого слоя, а также образованием структур $\mathrm{Fe}-\mathrm{C}$. Ионная бомбардировка приводит к дальнейшему существенному увеличению степени разупорядочения углеродного слоя (спектр 4). Полосы $D$ и $G$ практически не разрешены, соотношение $D / G$ - выше единицы, а провал между ними полностью отсутствует. Интенсивность спектра левее $D$-полосы возрастает. На основании этих данных мы можем утверждать о формировании разупорядоченной, вплоть до аморфной, структуры пленки углерода, находящегося преимущественно в $s p^{2}$ гибридизованном состоянии, а также возрастании доли структур нестехиометрических карбидов железа, что находится в согласии с данными РФЭС границы раздела пленка-подложка.

\section{4. Выводы}

По данным РФЭС, углерод по глубине поверхностных слоев находится в нескольких неэквивалентных химических состояниях. На $\mathrm{C} 1 s$-спектрах углеродных пленок до и после ионной обработки присутствуют признаки, связанные с разупорядочением и наличием $s p^{2}$ - и $s p^{3}$-гибридизованного углерода. На границе раздела в зоне перемешивания образуются химические связи $\mathrm{C}-\mathrm{Fe}$, характерные для карбидов. Методом PCA выявлено образование структурных неоднородностей в переходной области „пленка-металл“. Рефлексы упорядоченной структуры графита на дифрактограммах не обнаружены. Результаты EELFS-спектроскопии позволяют предполагать о сильно разупорядоченной структуре сверхтонкого $(\sim 5 \mathrm{~nm})$ поверхностного слоя пленки и переходной области пленка-металл. По данным спектроскопии комбинационного рассеяния света, при магнетронном напылении изначально формируется пленка со структурой разупорядоченного углерода с преимущественно $s p^{2}$ гибридизацией. При последующей ионной бомбардировке степень разупорядочения возрастает. Особенности спектров КР в области $\Delta v \sim 1100 \mathrm{~cm}^{-1}$ позволяют утверждать об аморфизации углеродного слоя и наличии углерода с $s p^{3}$-гибридизацией валентных электронов.

\section{Список литературы}

[1] A.C. Ferrari, J. Robertson. Raman spectroscopy of amorphous, nanostructured, diamond-like carbon, and nanodiamond. Phil. Trans. R. Soc. Lond. A 362, 2477 (2004).

[2] J. Robertson. Mater. Sci. Eng. 37, 129 (2004).

[3] S.T. Jackson, R.G. Nuzzo. Appl. Surf. Sci. 90, 195 (1995).

[4] А.В. Тюрина, Д.В. Серов, А.Н. Образцов. Физико-химия поверхности и защита материалов 45, 6, 505 (2009).

[5] А.А. Золотухин, А.Н. Образцов, А.О. Устинов. ЖЭТФ 124, 6, 1291 (2003).

[6] А. Усеинов, К. Гоголинский. Наноиндустрия 5, 54 (2010).

[7] М.С. Зибров, А.А. Писарев, Г.В. Ходаченко, Д.В. Мозгрин. Успехи прикладной физики 1, 2, 167 (2013).

[8] Z. Khalaj, M. Ghoranneviss, E. Vaghri, A. Saghaleni, M. Diudea. Acta Chim. Slov. 59, 2, 338 (2012).

[9] Ю.В. Плесков, М.Д. Кротова, С.М. Пименов. Электрохимия 46, 3, 333 (2010).

[10] И.А. Курзина, Э.В. Козлов, Ю.П. Шаркеев. Нанокристаллические интерметаллидные и нитридные структуры, формирующиеся при ионно-лучевом воздействии. Изд-во НТЛ, Томск (2008). 324 с. 
[11] С.М. Решетников, О.Р. Бакиева, Е.М. Борисова, В.Л. Воробьев, Ф.З. Гильмутдинов, А.А. Колотов, В.Ф. Кобзиев, В.В. Мухгалин, В.Я. Баянкин, С.Г. Быстров, А.А. Шушков. Коррозия: материалы, защита 11, 1 (2015).

[12] А.Ф. Буренков, Ф.Ф. Комаров, М.А. Кумахов, М.М. Темкин. Таблицы параметров пространственного распределения ионно-имплантированных примесей. Изд-во БГУ, Минск (1980). 352 с.

[13] M. De Crescenzi. Critic. Rev. Solid State Mater. Sci. 15, 3, 279 (1989).

[14] D. Guy, O. Bakieva, V. Grebennikov, D. Surnin, Y. Ruts. J. Electron Spectroscopy Related Phenomena 182, 115 (2010).

[15] Д.Е. Гай, О.Р. Бакиева, Д.В. Сурнин. Журн. структурн. химии 52, 171 (2011).

[16] В.И. Нефедов. Рентгенгоэлектронная спектроскопия химических соединений. Справочник. Химия, М. (1984). 256 с.

[17] С.С. Букалов, Л.А. Михалицын, Я.В. Зубавичус, Л.А. Лейтес, Ю.Н. Новиков. Рос. хим. журнал 1, 1, 83 (2006). 